Section Editor

John J. Millichap, MD

\title{
Teaching NeuroImages:
}

Hypoglossal nerve palsy due to basilar invagination

Joshua Bakhsheshian, MD, MS

Khodayar Goshtasbi, BS Jay Acharya, MD

Ian A. Buchanan, MD

Vance Fredrickson, MD

Patrick Reid, MD

Correspondence to

Dr. Bakhsheshian:

Joshuabakh@gmail.com
A woman in her 50 s presented to the emergency room with complaints of gait instability. Her examination was notable for tongue deviation to the left. Imaging demonstrated basilar invagination and compression of the preolivary sulci near the cranial nerve 12 nerve root exit zone (figures 1 and 2). Basilar invagination is a rare craniocervical malformation, which can cause neurologic deficits and instability of the craniocervical junction. ${ }^{1,2}$ Imaging is also notable for platybasia, which is often associated with basilar invagination. The patient underwent a posterior occiput-C3 decompression and fusion without any complications. The patient had a stable neurologic examination on 3-month follow-up.

\section{AUTHOR CONTRIBUTIONS}

Joshua Bakhsheshian: drafting/revising the manuscript for content, including medical writing for content, study concept or design, analysis or interpretation of data, accepts responsibility for conduct of research and final approval. Khodayar Goshtasbi, Jay Acharya, Ian A. Buchanan, Vance Fredrickson: acquisition of data, analysis or interpretation of data, accepts responsibility for conduct of research and final approval. Patrick Reid: acquisition of data, analysis or interpretation of data, accepts responsibility for conduct of research and final approval.

\section{STUDY FUNDING}

No targeted funding reported.

\section{DISCLOSURE}

The authors report no disclosures relevant to the manuscript. Go to Neurology.org for full disclosures.

\section{REFERENCES}

1. Chaudhry NS, Ozpinar A, Bi WL, et al. Basilar invagination: case report and literature review. World Neurosurg 2015;83:1180.e7-1180.e11.

2. Lee CH, Casey AT, Allibone JB, Chelvarajah R. Trombone tongue: a new clinical sign for significant medullary compression at the craniovertebral junction: case report. J Neurosurg Spine 2006;5:550-553.

Figure 1 Three-dimensional reconstruction of CT craniocervical junction
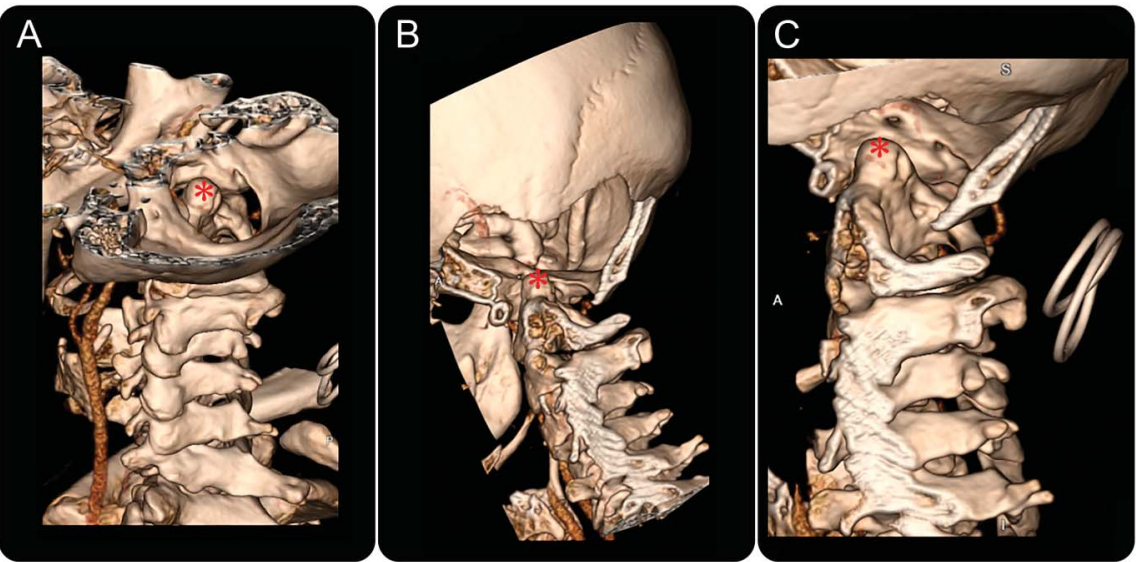

Images demonstrate cranial to caudal (A) and parasagittal views $(\mathrm{B}, \mathrm{C})$ highlighting the upward displacement of $\mathrm{C} 2$ (dens marked with *) relative to the basion.

Download teaching slides: Neurology.org

From the Departments of Neurological Surgery (J.B., I.A.B., V.F., P.R.) and Neuroradiology (J.A.), Keck School of Medicine, University of Southern California, Los Angeles; and UC Irvine School of Medicine (K.G.). 

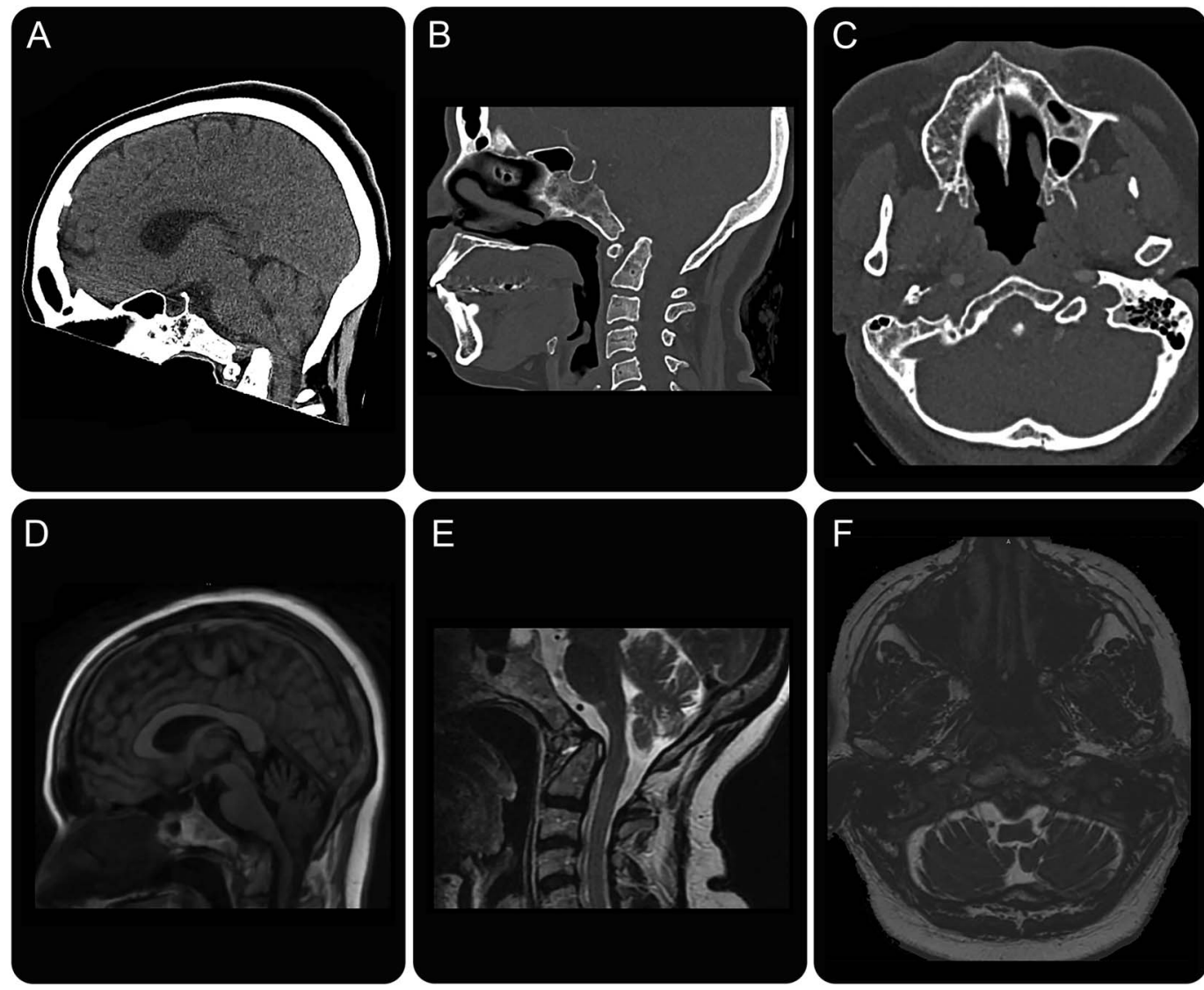

Imaging demonstrates basilar invagination (A: CT head; B, C: CT cervical spine), C1-C2 autofusion, and atrophy of the medulla (D: MRI brain T1-weighted; E: MRI cervical spine T2-weighted; F: MRI brain fast imaging employing steady-state acquisition). The dens was noted near the left hypoglossal canal (C) while also compressing the preolivary sulci near the region of the cranial nerve 12 nerve root exit zone $(F)$. 


\section{Neurology}

Teaching NeuroImages: Hypoglossal nerve palsy due to basilar invagination Joshua Bakhsheshian, Khodayar Goshtasbi, Jay Acharya, et al.

Neurology 2017;89;e214-e215

DOI 10.1212/WNL.0000000000004571

This information is current as of October 23, 2017

\begin{tabular}{|c|c|}
\hline $\begin{array}{l}\text { Updated Information \& } \\
\text { Services }\end{array}$ & $\begin{array}{l}\text { including high resolution figures, can be found at: } \\
\text { http://n.neurology.org/content/89/17/e214.full }\end{array}$ \\
\hline Supplementary Material & $\begin{array}{l}\text { Supplementary material can be found at: } \\
\text { http://n.neurology.org/content/suppl/2017/10/19/WNL.0000000000004 } \\
\text { 571.DC1 }\end{array}$ \\
\hline References & $\begin{array}{l}\text { This article cites } 2 \text { articles, } 0 \text { of which you can access for free at: } \\
\text { http://n.neurology.org/content/89/17/e214.full\#ref-list-1 }\end{array}$ \\
\hline Subspecialty Collections & $\begin{array}{l}\text { This article, along with others on similar topics, appears in the } \\
\text { following collection(s): } \\
\text { All Imaging } \\
\text { http://n.neurology.org/cgi/collection/all_imaging } \\
\text { All Spinal Cord } \\
\text { http://n.neurology.org/cgi/collection/all_spinal_cord }\end{array}$ \\
\hline Permissions \& Licensing & $\begin{array}{l}\text { Information about reproducing this article in parts (figures,tables) or in } \\
\text { its entirety can be found online at: } \\
\text { http://www.neurology.org/about/about_the_journal\#permissions }\end{array}$ \\
\hline Reprints & $\begin{array}{l}\text { Information about ordering reprints can be found online: } \\
\text { http://n.neurology.org/subscribers/advertise }\end{array}$ \\
\hline
\end{tabular}

Neurology ${ }^{\circledR}$ is the official journal of the American Academy of Neurology. Published continuously since 1951, it is now a weekly with 48 issues per year. Copyright () 2017 American Academy of Neurology. All rights reserved. Print ISSN: 0028-3878. Online ISSN: 1526-632X.

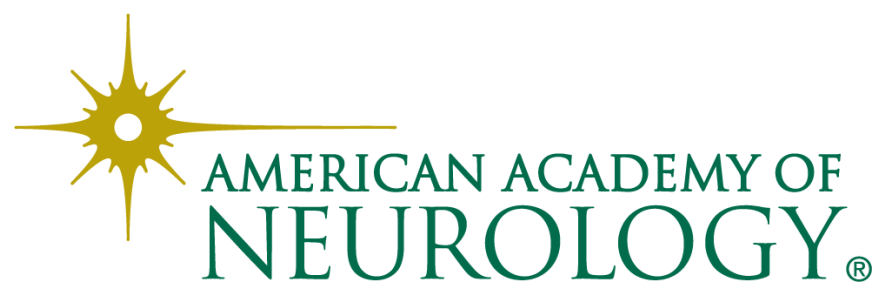

